\title{
Herbicide Clomazone Detection Using Electroanalytical Approach Using Boron Doped Diamond Electrode
}

\author{
Sladjana Djurdjic ${ }^{1, *}$, Vesna Vukojević ${ }^{1}$, Sonja Jevtic ${ }^{2}$, Marija V. Pergal $^{3}$, Branka B. Petkovic $^{2}$, \\ Dalibor M. Stankovic ${ }^{1,4, *}$ \\ ${ }^{1}$ Innovation center of the Faculty of Chemistry, University of Belgrade, POB 51, 118, 11158 Belgrade, \\ Serbia \\ ${ }^{2}$ Depatment of Chemistry, Faculty of Natural Science and Mathematics, University of Priština, Lole \\ Ribara 29, 38220 Kosovska Mitrovica, Serbia \\ ${ }^{3}$ ICTM, Center of Chemistry, University of Belgrade, Njegoševa 12, 11000 Belgrade, Serbia \\ ${ }^{4}$ The Vinca Institute of Nuclear Sciences, University of Belgrade, POB 522, 11001 Belgrade, Serbia \\ *E-mail: sladjanadj@chem.bg.ac.rs, dalibors@chem.bg.ac.rs, daliborstankovic@vin.bg.ac.rs
}

doi: $10.20964 / 2018.03 .39$

Received: 21 November 2017 / Accepted: 8 January 2018 / Published: 5 February 2018

In this work, for the first time we proposed electrochemical behavior and development of an analytical procedure for quantification of pesticide clomazone. Electrochemical behavior of clomazone's at boron-doped diamond electrode is characterized with irreversible oxidation at potential of around 1.6 $\mathrm{V}$, in Britton-Robinson buffer solution at $\mathrm{pH}$ 2. It was found that potential of this oxidation was not $\mathrm{pH}$ dependent excluding presence of proton in the electrochemical reaction. Square wave voltammetry method was the most appropriate for clomazone quantification and proposed procedure was successfully applied for determination of clomazone in river water samples. Obtained parameters, detection limit of $0.21 \mu \mathrm{M}$ and working linear range from 1 to $100 \mu \mathrm{M}$ and satisfied selectivity can indicate that presented results open new field in research of this group of pesticides and offer possible replacement to the sophisticated and expensive chromatographic methods.

Keywords: clomazone; electrochemistry; boron doped diamond electrode;

\section{$\underline{\text { FULL TEXT }}$}

(C) 2018 The Authors. Published by ESG (www.electrochemsci.org). This article is an open access article distributed under the terms and conditions of the Creative Commons Attribution license (http://creativecommons.org/licenses/by/4.0/). 